\title{
Penerapan Multimedia Interaktif Untuk Meningkatkan Motivasi Belajar dan Hasil Belajar Siswa Pada Pembelajaran IPA
}

\author{
Martin Kahfi ${ }^{\# 1}$, Erna Srirahayu ${ }^{\# 2}$, Nurparida ${ }^{\# 3}$ \\ \#Program Studi Teknologi Pendidikan, Pascasarjana Institut Pendidikan Indonesia Garut \\ Jl. Terusan Pahlawan No.32, Sukagalih, Kec. Tarogong Kidul, Kabupaten Garut \\ ${ }^{1} \mathrm{mr}$.caviedgmail.com \\ 2nurparida9egmail.com, \\ 3ernasrirahayu9egmail.com
}

\begin{abstract}
The purpose of this study is to use interactive multimedia in learning so that teachers can learn abstract information to be more concrete. The method used was an experimental method with a population of class V SDN 2 Keresek and a sample of 21 students. The results showed an increase in learning motivation based on the test results of 0.72 with high interpretation. Furthermore, the increase in student learning outcomes is 0.33 in the medium category. The application of interactive multimedia can increase learning motivation and student learning outcomes in grade V SDN 2 Keresek learning science.
\end{abstract}

Keywords_Learning Outcomes, Learning Motivation, Interactive Multimedia.

Abstrak - Tujuan penelitian ini menggunakan multimedia interaktif dalam pembelajaran agar guru dapat mempelajari informasi yang bersifat abstrak menjadi lebih konkret. Metode yang digunakan adalah metode eksperimen dengan populasi kelas V SDN 2 Keresek dan sampel yang diambil sebanyak 21 siswa. Hasil penelitian menunjukan peningkatan peningkatan motivasi belajar berdasarkan hasil uji sebesar 0,72 dengan interpretasi tinggi. Selanjutnya peningkatan hasil belajar siswa sebesar 0,33 dengan kategori sedang. Penerapan multimedia interaktif dapat meningkatkan motivasi belajar dan hasil belajar siswa kelas V SDN 2 Keresek pembelajaran IPA.

Kata Kunci : Hasil Belajar, Motivasi Belajar, Multimedia Interaktif.

\section{PENDAHULUAN}

Pendidikan di sekolah tidak terlepas dari proses kegiatan belajar mengajar yang merupakan perencanaan secara sistematis yang dibuat oleh guru dalam bentuk satuan pelajaran. Sebagai usaha sadar untuk meningkatkan kualitas pendidikan, seorang guru tentunya memerlukan strategi dan metode penyampaian materi yang tepat dalam mendisain suatu kegiatan pembelajaran yang dapat merangsang motivasi siswa dalam belajar sehingga didapatkan output yang diharapkan yaitu berupa hasil belajar yang sesuai dengan tujuan pembelajaran.

Tentang Standar Proses untuk Satuan Pendidikan Dasar dan Menengah menjelaskan bahwa Standar Proses meliputi perencanaan proses pembelajaran, pelaksanaan proses pembelajaran, penilaian hasil pembelajaran, dan pengawasan proses pembelajaran untuk terlaksananya proses pembelajaran yang efektif dan efisien. Proses pembelajaran pada setiap satuan pendidikan dasar dan menengah harus interaktif, inspiratif, menyenangkan, menantang, dan memotivasi peserta didik untuk berpartisipasi aktif, serta memberikan ruang yang cukup bagi prakarsa, kreativitas, dan kemandirian sesuai dengan bakat, minat, dan perkembangan fisik serta psikologis peserta didik.

Telah banyak inovasi dilakukan untuk meningkatkan kualitas pembelajaran, salah satu inovasi tersebut adalah model pembelajaran yang dapat berpengaruh terhadap proses dan hasil pembelajaran, inovasi dalam pengembangan model pembelajaran yang berkembang saat ini adalah model pembelajaran yang berorientasi pada siswa. Joice and Weil mengelompokkan model pembelajaran ke dalam empat bagian, yaitu model pemrosesan informasi (information processing models), model personal (personal family models), model social (social family), dan model perilaku (Behavioral model of teaching).

Saat ini perkembangan teknologi pembelajaran menjadi sangat penting dalam proses pembelajaran, bahwa untuk melaksanakan pembelajaran seorang guru harus mampu 
merancang pembelajaran dengan baik sehingga pada pelaksanaan pembelajaran dapat berjalan lancar. Untuk mendukung terhadap pelaksanaan pembelajaran tentu kiranya perlu ditunjang oleh pemanfaatan media dan sumber belajar yang relevan dengan kebutuhan belajar.

Di era globalisasi, banyak sekali teknologi multimedia yang dapat digunakan sebagai media pembelajaran di sekolah. Perpustakaan yang lengkap dengan buku-buku yang terbaru sebagai pusat sumber belajar masih sangat dibutuhkan oleh seluruh warga sekolah dalam proses pembelajaran. Demikian juga pemanfaatan media pembelajaran yang lainnya, yang saat ini sedang digalakkan, yaitu berbagai macam multimedia yang sangat cocok dengan kondisi dan situasi saat ini.

Dalam pelaksanaan pembelajaran, peran guru menjadi kunci utama dalam mengelola pembelajaran untuk mewujudkan tujuan pembelajaran yang telah ditetapkan yaitu adanya perubahan perilaku dan kemampuan peserta didik setelah mengikuti pembelajaran. Pada saat ini peran guru masih mendominasi pembelajaran di kelas dan menjadi

sumber utama informasi menyebabkan peran siswa pasif sebagai penerima informasi. Kondisi ini tentunya berdampak pada rendahnya kemampuan peserta didik dalam mengkontruksi pengetahuannya sendiri dikarenakan informasi yang diterima siswa hanya bersumber dari guru. Dalam pembelajaran seharusnya siswa lebih aktif dan kreatif dalam proses belajar.

Bahwa proses belajar terjadi melalui prilaku aktif siswa, yaitu apa yang dilakukan, ditemukan, dan dipelajari sehingga menjadi suatu pengetahuan baru bagi siswa, dan bukan apa yang dilakukan oleh guru. Tingkat kemampuan berfikir tertinggi siswa adalah ketika mereka melakukan investigasi, mengumpulkan, menyimpulkan dan mensintesis suatu informasi.

Pembelajaran matematik yang selama ini dilaksanakan dalam mengembangkan kemampuan berfikir tinggi belum optimal. Hal ini ditandai berdasarkan hasil pengamatan menunjukan sebagian besar peserta didik berperan pasif selama pelaksanaan pembelajaran. Peserta didik umumnya memandang bahwa mata pelajaran matematika sebagai mata pelajaran yang sulit, hal ini dibuktikan berdasarkan hasil wawancara dengan peserta didik. Keadaan ini menuntut guru untuk melakukan pembaruan terkait dengan program pembelajaran yang diterapkan dikelas. Pembaruan yang dilakukan terkait dengan penggunaan metode pembelajaran dan media pembelajaran sebagai alat untuk menyampikan materi pelajaran kepada peserta didik.

Keberhasilan pembelajaran sangat dipengaruhi oleh guru dalam merancang pembelajaran dan mengimplemtasikan program pembelajaran dikelas. Teknologi pendidikan merupakan penggabungan antara teknologi pembelajaran, teknologi belajar, teknologi perkembangan, teknologi pengelolaan dan teknologi-teknologi lain untuk keperluan pemecahan masalah-masalah pendidikan. Sedangkan teknologi pembelajaran dikatakan sebagai penerapan secara sistematik dan sistematis dan tehnik-tehnik yang dirumuskan dari berbagai teori untuk keperluan pemecahan masalahmasalah pembelajaran.

Dalam pelaksanaan pembelajaran di kelas sarana atau media pembelajaran termasuk teknologi pembelajaran yang sangat membantu guru dalam mencapai tujuan-tujuan pembelajaran.

Peran seorang pendidik sebagai pengembang ilmu sangat besar untuk memilih dan melaksanakan pembelajaran yang efektif dan efisien bagi peserta didik. Pembelajaran yang baik dapat ditunjang dari suasana pembelajaran yang kondusif serta hubungan komunikasi antara pendidik, peserta didik dapat berjalan dengan baik. Proses pembelajaran akan efektif manakala memanfaatkan berbagai sarana dan prasarana yang tersedia termasuk memanfaatkan berbagai sumber belajar.

Peserta didik dalam melakukan aktivitas belajar memerlukan adanya pendorong atau motivasi tertentu agar proses belajarnya dapat mencapai prestasi belajar sesuai dengan tujuan yang diiinginkan. Motivasi merupakan aspek yang sangat dominan untuk membantu seseorang mencapai tujuannya. Tanpa adanya motivasi seorang peserta didik tidak mungkin memiliki kemauan untuk belajar.

Dalam rangka membangkitkan motivasi, seorang pendidik harus dapat menunjukkan pentingnya pengalaman dan materi belajar bagi kehidupan peserta didik dengan demikian peserta didik akan melakukan proses pembelajaran bukan hanya mengejar nilai semata apalagi hanya untuk mendapat pujian saja, tetapi mereka belajar dengan penuh kesadaran untuk memenuhi kebutuhannya.

Tinggi rendahnya motivasi peserta didik dipengaruhi oleh faktor-faktor dari peserta didik itu sendiri, baik dari faktor instrinsik maupun ekstrinsik. Prestasi belajar berkaitan dengan pencapaian kompetensi sesuai dengan tujuan yang telah dirumuskan. Belajar ialah suatu usaha yang dilakukan seseorang untuk memperoleh suatu perubahan tingkah laku yang baru secara keseluruhan, sebagai hasil pengalamannya sendiri dalam interaksi dengan lingkungannya.

Prestasi belajar bisa merupakan kompetensi yang dapat diukur yang berupa pengetahuan, sikap dan keterampilan sebagai interaksi aktif antara subyek belajar dengan obyek belajar selama berlangsungnya proses belajar mengajar untuk mencapai hasil belajar.

Kemajuan dan perkembangan teknologi saat ini mengubah pengelolaan pembelajaran dikelas yang dirasa dapat membantu guru mengajar dan peserta didik untuk belajar telah memberikan banyak tawaran dan pilihan bagi dunia pendidikan untuk menunjang proses pembelajaran sehingga pembelajaran menjadi lebih efektif dan efisien bagi siswa. Kehadiran teknologi informasi dan komunikasi dapat dimanfaatkan sebagai media pembelajaran yang bisa dijadikan sebagai alat bantu guru dalam menyampaikan materi kepada peserta didik maupun sebagai sumber belajar.

Multimedia merupakan perpaduan antara berbagai media (format file) yang berupa teks, gambar, grafik, musik 
animasi, video, interaksi dan lain-lain, yang telah dikemas menjadi file digital (komputerisasi), serta digunakan untuk menyampaikan pesan kepada pengguna.

Sedangkan interaktif berkaitan dengan proses komunikasi dua arah atau lebih dari komponen-komponen komunikasi. Komponen komunikasi dalam multimedia interaktif adalah hubungan antara manusia sebagai user/pengguna dengan komputer sebagai alat yang memberikan informasi.

Teknologi multimedia telah menjanjikan potensi besar dalam merubah cara seseorang untuk belajar, untuk memperoleh informasi, menyesuaikan informasi dan sebagainya. Multimedia juga menyediakan peluang bagi pendidik untuk mengembangkan teknik pembelajaran sehingga menghasilkan hasil yang maksimal. Demikian juga bagi peserta didik, dengan multimedia diharapkan mereka akan lebih mudah untuk menentukan dengan apa dan bagaimana dapat menyerap informasi secara cepat dan efisien. Oleh karena itu, kehadiran multimedia dalam proses belajar menjadi sangat bermanfaat.

Media pembelajaran merupakan salah satu komponen yang penting dalam pembelajaran yang digunakan untuk menyalurkan pesan maupun informasi dari tenaga pendidik kepada peserta didik sehingga dapat merangsang pikiran, perasaan, perhatian, dan kemauan siswa untuk belajar. Media yang dapat dimanfaatkan dalam pembelajaran salah satunya multimedia interaktif.

Multimedia interaktif adalah suatu tampilan multimedia yang dirancang memuat fungsi interaktif kepada penggunanya [1] Penggunaan aplikasi multimedia interaktif dalam pembelajaran akan meningkatkan efisiensi, motivasi, serta memfasilitasi belajar aktif, belajar eksperimental, konsisten, dengan belajar yang berpusat pada siswa[2]. Hasil penelitian mengenai penerapan multimedia interaktif telah memberikan pengaruh yang signifikan serta efektif dalam pembelajaran[3] [4].

Berdasarkan hasil observasi di SDN 2 Keresek siswa kelas V Pelaksanaan pembelajaran masih menggunakan metode ceramah yang berdampak pada rendahnya aktivitas belajar siswa. Selanjutnya sebagian besar nilai rata-rata hasil belajar siswa pada mata pelajaran IPA belum mencapai KKM. Tujuan penelitian ini adalah untuk mengetahui peningkatan motivasi dan hasil belajar siswa kelas V SDN 2 Keresek pada pembelajaran IPA.

\section{TINJAUAN PUSTAKA}

\section{A. Media Pembelajaran}

Bahwa media pembelajaran adalah sesuatu alat yang secara fisik digunakan untuk menyampaikan isi materi pembelajaran. Media pembelajaran tersebut dapat berupa buku, tape recorder, kaset video, film, slide, foto, gambar, televise, dan komputer. Berdasarkan pendapat ahli tersebut, dapat disimpulkan bahwa media pembelajaran adalah suatu alat yang dapat dilihat, didengar, dan diraba oleh pancra indera manusia. Alat tersebut digunakan oleh guru dalam proses pembelajaran, sehingga tujuan pembelajaran dapat tercapai dengan baik. Media pembelajaran menurut Danim (1995:7) adalah media pendidikan yang merupakan seperangkat alat bantu atau pelengkap yang digunakan oleh guru atau pendidik dalam rangka berkomunikasi dengan siswa atau peserta didik. Berdasarkan pernyataan tersebut, dapat disimpulkan bahwa media pembelajaran merupakan segala sesuatu yang digunakan oleh guru untuk menyampaikan informasi berupa materi pelajaran kepada penerima pesan.

Media pembelajaran adalah bermacam peralatan digunakan guru untuk menyampaikan pesan ajaran kepada siswa melalui penglihatan dan pendengaran,. Jadi, media pembelajaran adalah alat bantu yang dapat dilihat, dibaca, didengar. Alat tersebut digunakan oleh guru sebagai alat bantu mengajar. Dalam interaksi pembelajaran, guru menyampaikan pesan ajaran berupa materi pembelajaran kepada siswa.

Berdasarkan beberapa pendapat para ahli tersebut, peneliti mengambil kesimpulan bahwa yang dimaksud dengan media pembelajaran adalah suatu alat bantu fisik, yang dapat digunakan oleh manusia dengan panca indera dan anggota tubuh seperti tangan. Alat tersebut merupakan alat perantara dalam menyampaikan gagasan materi pelajaran. Materi pelajaran tersebut dikaitkan dalam situasi yang nyata. Gagasan materi tersebut, disampaikan melalui media pembelajaran dan ditujukan kepada penerima yaitu peserta didik. Media pembelajaran dapat memperjelas penyajian pesan dan informasi sehingga dapat memperlancar dan meningkatkan proses dan hasil belajar.

a. Media pembelajaran dapat meningkatkan dan mengarahkan perhatian anak sehingga dapat menimbulkan motivasi belajar, interaksi yang lebih langsung antara siswa dan lingkungannya dan kemungkinan siswa untuk belajar sendiri-sendiri sesuai dengan kemampuan dan minatnya.

b. Media pembelajaran dapat mengatasi keterbatasan indera, ruang dan waktu.

c. Media pembelajaran dapat memberikan kesamaan pengalaman kepada siswa tentang peristiwa-peristiwa di lingkungan mereka, serta memungkinkan terjadinya interaksi langsung dengan guru, masyarakat dan lingkungannya.

Media pembelajaran juga mempunyai manfaat bagi proses pembelajaran menurut Commission on Instructional Tegnology manfaat tersebut adalah :

1. Membuat pendidikan lebih produktif,

2. Menunjang pengajaran individual,

3. Kegiatan pengajaran lebih ilmiah,

4. Pengajaran lebih maksimal,

5. Kegiatan belajar lebih menghubungkan dengan realita,

6. Mempercepat pendidikan dengan memperkaya teknologi. 


\section{B. Multimedia Interaktif}

Multimedia adalah pemanfaatan banyak media yang digunakan dalam suatu proses interaksi penyampaian pesan dari sumber pesan kepada penerima pesan [5]. Komponen dalam multimedia memuat kombinasi teks, grafik, audio, gambar bergerak disertai dengan link dan tools yang terintegrasi pada satu aplikasi[1][6].

Sebagian dari multimedia adalah interaktif, dimana pengguna dapat menekan mouse atau objek pada screen seperti button atau teks dan menyebabkan program melakukan perintah tertentu[7]. Dalam konteks pembelajaran dalam penggunaan multimedia sebagai media pembelajaran fungsi guru sebagai pemberi pesan dan peserta didik sebagai penerima pesan.

Media pembelajaran multimedia interaktif merupakan alat atau sarana pembelajaran yang berisi materi, metode, batasan-batasan, dan cara mengevaluasi yang dirancang secara sistematis dan menarik untuk mencapai kompetensi/subkompetensi mata pelajaran yang diharapkan sesuai dengan tingkat kompleksitasnya.[8][9], menjelaskan dalam kegiatan pembelajaran di kelas, multimedia dapat berfungsi sebagai: (1) suplemen yang sifatnya opsional, multimedia dikatakan sebagai suplemen (tambahan); (2) pelengkap (komplemen); (3) substitusi (pengganti).

\section{Motivasi Belajar}

Kata motivasi berasal dari kata motif yang merupakan daya dorong yang muncul dari dalam diri individu untuk melakukan suatu aktivitas maupun perbuatan yang ditunjukan dalam bentuk motivasi untuk mencapai tujuan tertentu. Motivasi adalah daya penggerak yang telah menjadi aktif [10]. Selanjutnya menurut [11] motivasi adalah suatu set yang dapat membuat individu melakukan kegiatan-kegiatan tertentu untuk mencapai tujuan. Dapat disimpulkan bahwa motivasi merupakan suatu daya pendorong dari individu dalam melakukan aktivitasnya guna mewujudkan tujuan tertentu.

Bahwa motivasi adalah suatu perubahan energi dalam diri (pribadi) seseorang yang ditandai dengan timbulnya perasaan dan reaksi untuk mencapai tujuan. Motivasi dimulai dari adanya perubahan energi dalam pribadi. Perubahan tersebut terjadi disebabkan oleh perubahan tertentu pada sistem neurofisolgis dalam organisme manusia, misalnya karena terjadinya perubahan dalam sistem pencernaan maka timbul motif lapar. Disamping itu, ada juga perubahan energi yang tidak diketahui.

a. Motivasi ditandai oleh timbulnya perasaan (affective arousal). Mula-mula berupa ketegangan psikologis, lalu berupa suasana emosi. Suasana emosi ini menimbulkan tingkah laku yang bermotif. Suasana emosi ini menimbulkan tingkah laku yang bermotif. Perubahan ini dapat diamati pada perbuatannya. Contohnya seseorang terlibat dalam suatu diskusi, dia tertarik pada masalah yang sedang dibicarakan, karenanya dia bersuara/mengemukakan pendapatnya dengan kata-kata yang lancar dan cepat. b. Motivasi ditandai oleh reaksi-reaksi untuk mencapai tujuan. Pribadi yang bermotivai memberikan responsrespons ke arah suatu tujuan tertentu. Respons-respons itu berfungsi mengurangi ketegangan yang disebabkan oleh perubahan energi dalam dirinya.

Motivasi pada umumnya didefinisikan sebagai sesuatu yang mendorong seseorang untuk melakukan tindakan. Motivasi adalah suatu faktor internal yang menggugah, mengarahkan dan mengintegrasikan tingkah laku seseorang yang didorong oleh kebutuhan, kemauan dan keinginan yang menyebabkan timbulnya perasaan yang kuat untuk memenuhi kebutuhan. Motivasi adalah kondisi yang muncul dalam diri individu yang disebabkan oleh interaksi antara motif dengan kejadian-kejadian yang diamati oleh individu, sehingga mendorong mengaktifkan perilaku menjadi tindakan nyata.

Menurut pendapat para ahli di atas dapat disimpulkan bahwa motivasi adalah suatu dorongan dalam diri seseorang yang mendorong individu tersebut dapat melakukan aktivitas-aktivitas tertentu untuk mencapai suatu tujuan yang diinginkan yang didapat dari pengalamannya yang diperoleh dari lingkungan dan ia yakin bahwa dirinya itu mampu untuk melakukan guna mencapai keinginannya Fungsi dari motivasi adalah :

1. Mendorong timbulnya tingkah laku atau perbuatan.

2. Motivasi berfungsi sebagai pengarah, artinya mengarahkan perbuata untuk mencapai tujuan yang diinginkan.

3. Motivasi berfungsi sebagai penggerak, artinya menggerakan tingkah laku seseorang.

Guru bertanggung jawab melakasanakan sistem pembelajaran agar berhasil dengan baik. Keberhasilan ini bergantung pada upaya guru membangkitkan motivasi belajar peserta didiknya. Motivasi mengandung nilai-nilai sebagai berikut :

1. Motivasi menentukan tingkat berhasil atau gagalnya kegiatan belajar peserta didik.

2. Pembelajran yang bermotivasi pada hakikatnya adalah pembelajran yang sesuai dengan kebutuhan, dorongan, motif, minat yang ada pada diri peserta didik.

3. Pembelajaran yang bermotivasi menuntut kreativitas dan imajinasi guru untuk berupaya secara sungguhsungguh mencari cara-cara relevan dan serasi guna membangkitkan dan memelihara motivasi belajar peserta didik.

4. Berhasil atau gagalnya dalam membangkitkan dan mendayagunakan motivasi dalam proses pembelajaran berkaitan dengan upaya pembinaan displin kelas.

5. Penggunaan asas motivasi merupakan sesuatu yang esensial dalam proses belajar dan pembelajaran.

Prinsip-prinsip motivasi belajar sebagai berikut :

1. Pujian lebih efektif daripada hukuman.

2. Para peserta didik mempunyai kebutuhan psikologis yang bersifat dasar yang perlu mendapat kepuasan. 
3. Motivasi bersumber dari dalam diri individu lebih efektif daripada motivasi yang berasal dari luar.

4. Tingkah laku (perbuatan) yang serasi perlu dilakukan penguatan.

5. Motivasi mudah menjalar kepada orang lain.

6. Pemahaman yang jelas terhadap tujuan-tujuan akan merangsang motivasi belajar.

7. Tugas-tugas yang dibebankan oleh diri sendiri akan menimbulkan minat yang lebih besar untuk melaksanakannya daripada tugas-tugas yang dipakasakan dari luar.

8. Ganjaran yang bersal dari luar kadang-kadang diperlukan dan cukup efektif untuk merangsang minat belajar.

9. Teknik dan prosedur pembelajaran yang bervariasi adalah efektif untuk memelihara minat peserta didik.

Untuk memperoleh hasil belajar yang optimal, guru dituntut kreatif membangkitkan motivasi belajar peserta didik. Beberapa petunjuk untuk membangkitkan motivasi peserta didik;

1. Memperjelas tujuan yang dicapai.

2. Membangkitkan minat peserta didik.

3. Menciptakan suasana yang menyenangkan dalam belajar.

4. Berilah pujiam yang wajar.

5. Berikan penilaian.

6. Berilah Komentar terhadap hasil pekerjaan peserta didik.

7. Ciptakan persaingan dan kerja sama

Belajar merupakan proses yang dilakukan oleh individu untuk mengubah perilakunya yang meliputi pengetahuan, sikap, dan keterampilan. Berkenaan dengan aktivitas belajar siswa sangat erat kaitannya dengan motivasi siswa sebagai daya pendorong untuk melakukan proses belajar.

Motivasi belajar siswa menjadi bagian yang perlu diperhatikan oleh tenaga pendidik mengingat motif dari dalam diri peserta didik perlu ditanamkan dan didorong untuk menarik antusias dan perhatian siswa melakukan aktivitas belajarnya. Dapat diakatakan siswa memiliki motivasi yang tinggi apabila siswa menunjukan tingkah laku yang aktif dalam melakukan aktivitas belajar sebaliknya apabila siswa menunjukan perilaku yang tidak aktif berarti motivasi belajarnya rendah.

Motivasi belajar siswa menjadi faktor yang sangat penting guna memberikan respon yang baik terhadap pembelajaran dalam mencapai tujuan pembelajaran yang diharapkan. Motivasi belajar adalah keseluruhan daya penggerak psikis didalam siswa yang menimbulkan kegiatan belajar itu demi mencapai suatu tujuan[12]. Selanjutnya menurut[13] motivasi belajar adalah dorongan internal dan eksternal pada siswa yang sedang belajar untuk mengadakan tingkah laku, pada umumnya dengan beberapa indikator atau unsur-unsur yang mendukung.

\section{Hasil Belajar}

Proses pembelajaran merupakan proses yang dirancang sedemikian rupa oleh tenaga pendidik untuk membantu aktivitas belajar siswa dalam mencapai hasil belajar yang diharapkan. Hasil belajar sebagai salah satu indicator keberhasilan pelaksanaan pembelajaran yang telah dilakukan oleh tenaga pendidik. Apabila hasil belajar siswa dapat tercapai dengan baik maka dapat dikatakan proses pembelajaran efektif.

Hasil belajar adalah kemampuan-kemampuan yang dimiliki siswa setelah siswa menerima pengalaman belajarnya. Pengalaman belajar yang dimaksud adalah aktivitas yang dilakukan siswa untuk menguasai kompetensi tertentu yang telah ditetapkan oleh guru setelah selesai mengikuti pembelajaran.

Menurut[14], hasil belajar merupakan dampak dari segala proses memperoleh pengetahuan, hasil dari latihan, hasil dari proses perubahan tingkah laku yang dapat diukur baik melalui tes perilaku, tes kemampuan kognitif, maupun tes psikomotorik. Berdasarkan para ahli maka dapat disimpulkan bahwa hasil belajar merupakan kompetensi yang dimiliki oleh siswa yang mencakup kemampuan kognitif, afektif, dan psikomotorik setelah mengikuti pembelajaran yang diperoleh melalui pengukuran dan penilaian test hasil belajar yang dilakukan oleh guru.

\section{METODE PENELITIAN}

Penelitian ini menggunakan pendekatan kuantitatif yang diterapkan untuk mengetahui hasil belajar siswa pada pembelajaran IPA yang selama ini berlangsung di SDN 2 Keresek Kabupaten Garut sebelum dan sesudah pemberian pembelajaran IPA dengan menggunakan multimedia interaktif Metode penelitian dengan menggunakan bentuk kuasi eksperimen, yaitu desain penelitian eksperimen yang merupakan pengembangan dari desain eksperimen sejati, melalui Non equivalen (Control Group Design) [15].

Desain penelitian quasi ada pengontrolan dalam penelitian pada kelompok kontrol atau pembenading, dalam penelitaina ini dilakukan test awal sebelum diberi perlakuan dan tes akhir setelah diberi perlakuan pada kelompok eksperimen [16]. Ada dua kelompok yang dipilih, yaitu kelompok eksperimen dan kelompok kontrol, memperoleh pretest dan postest. Perbedaan hasil pada kelompok eksperimen dan kelompok kontrol dapat menunjukkan adanya pengaruh atau tidaknya serta efektif atau tidaknya penggunaan multimedia Interaktif dalam pembelajaran yang diberikan kepada kelas eksperimen.

Desain penelitian yang dilakukan dengan bentuk kuasi eksperimen ini dikhususkan kepada bentuk "Non Equipalent Control Giroup Design". Dalam desain ini terdapat pretest, sebelum dilakukan perlakuan sama seperti pada bentuk pretest-posttest control group design didesain eksperimen sejati, hanya pada desain ini kelompok eksperimen dan maupun kelompok kontrol tidak dipilih secara random atau acak [17].

Penelitian yang dilakukan oleh peneliti diharapkan dapat memberikan gambaran secara mendalam mengenai "Penerapan multimedia interaktif untuk meningkatkan motivasi belajar dan hasil belajar siswa pada pembelajaran IPA". 
Populasi adalah keseluruhan subjek penelitian yang memberikan data. penelitian, atau juga diartikan sebagai wilayah generalisasi yang terdiri atas obyek atau subyek yang mempunyai kualitas dan karakteristik tertentu yang di tetapkan oleh peneliti untuk dipelajari dan ditarik kesimpulannya. Populasi dalam penelitian ini adalah seluruh siswa kelas V di SDN 2 Keresek Kabupaten Garut.

Sampel adalah bagian dari jumlah dan karakteristik yang dimilki oleh populasi. Karena penelitian ini berbentuk kuasi eksperimen maka dari populasi kelas $\mathrm{V}$ yang ada, dipilih dua kelas sebagai subjek sampel, siswa kelas V A sebanyak 21 siswa sebagai kelompok eksperimen yang menggunakan multimedia interaktif dan satu kelas yang lain, yaitu kelas V B sebanyak 21 siswa sebagai kelas kontrol.

Bentuk instrumen yang digunakan dalam penelitian ini, yaitu instrumen berupa tes Instrumen tes dilakukan untuk mengukur penguasaan konsep pembelajaran yang dimiliki siswa sebelum ataupun sesudah proses pembelajaran dilaksanakan melalui pretest dan postest.

Dalam sebuah kuantitatif, analisis data merupakan kegiatan yang dilakukan setelah data dari seluruh responden terkumpul. Teknik analisis data dalam penelitian kuantitatif menggunakan statistik. Metode analisis data yang digunakan untuk menguji objek penelitian ini, penulis menggunakan statistik inferensial, karena statistik ini digunakan untuk menganalisis data sampel dan hasilnya diberlakukan untuk populasi [16].

Kemudian dari statistik inferensial ini, penulis menggunakan uji statistik parametrik. Statistik parametrikk digunakan untuk menguji parameter populasi melalui statistik atau menguji ukuran populasi melalui data sampel (pengertian statistik disini adalah data yang diperoleh dari sampel). Parameter populasi itu meliputi rata-rata dengan notasi $\mu$ (mu), simpangan baku $\square$ (sigma), dan varians $\square 2$.

Sedangkan statistiknya adalah meliputi rata-rata (Xbar), simpangan baku s, dan varians s2. Jadi parameter populasi yang berupa $\square$ diuji melalui , selanjutnya $\square$ diuji melalui s, $\square$ 2diuji melalui s2 dalam statistik, pergujian parameter melalui statistik data sampel tersebut dinamakan uji hipotesis statistik. Oleh karena itu, penelitian yang berhipotesis statistik adalah penelitian yang menggunakan data sampel.

Dalam statistik hipotesis yang diuji adalah hipotesis nol, karena tidak dikehendaki adanya perbedaanantara parameter populasi dan statistik (data yang diperoleh dari sampel). Data yang dikumpulkan merupakan data dengan skala interval serta berlandaskan pada ketentuan bahwa data yang akan dianalisis berdistribusi normal [16].

Teknik analisis data yang digunakan dalam penelitian ini, yakni analisis statistik deskriptif dan analisis statistik inferensial. Analisis slalistik deskriptif bertujuan untuk mengetahui pengaruh multimedia interaktif melalui instrumen dengan cara melihat tingkat penguasaan materi dan penggambaran karakteristik distribusi nilai pencapaian hasil belajar IPA siswa yang diajar dengan menggunakan multimedia interaktif pembelajaran maupun siswa yang diajar menggunakan metode konvensional, yang terdiri dari nilai rata-rata (mean), standar deviasi, nilai tertinggi (maksimum), dan nilai terendah (minimum) dengan menggunakan sistem pengolahan Ms. Excel [18].

Uji perbedaan penguasaan konsep pembelajaran pada aspek mengingat dan aspek memahami antara kelas eksperimen dengan kelas kontrol dengan menggunakan uji t dua rata-rata.

\section{HASIL DAN PEMBAHASAN}

\section{A. Hasil Penelitian}

Motivasi belajar siswa diukur dengan menggunakan kuesioner yang diberikan kepada peserta didik yang berjumlah 21 orang. Tujuan penyebaran kuesioner untuk mengetahui motivasi belajar dalam merespons pembelajaran dengan menggunakan multimedia interaktif.

Penyebaran kuesioner dilakukan sebelum dan sesudah pemberian perlakuan penggunaan multimedia interaktif Berdasarkan hasil uji gain ternormalisasi peningkatan motivasi belajar siswa diperoleh data sebagai berikut ;

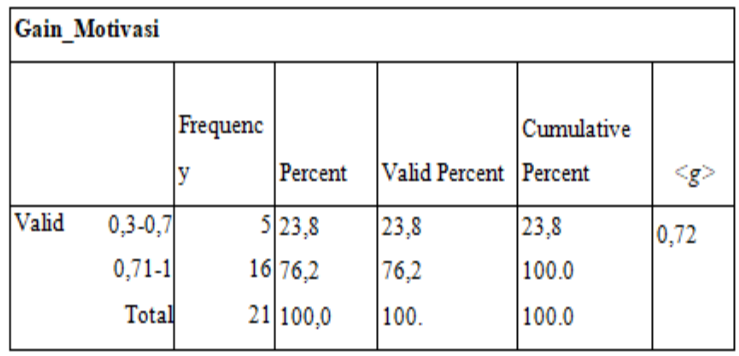

Gambar 1. Peningkatan Motivasi Belajar Siswa

Peningkatan motivasi belajar siswa sebelum dan sesudah pembelajaran diperoleh nilai 0,72 . Hal ini menunjukan bahwa peningkatan motivasi belajar siswa pada pembelajaran IPA dengan menggunakan multimedia interaktif dengan nilai gain 0,72 pada kategori tinggi [19].

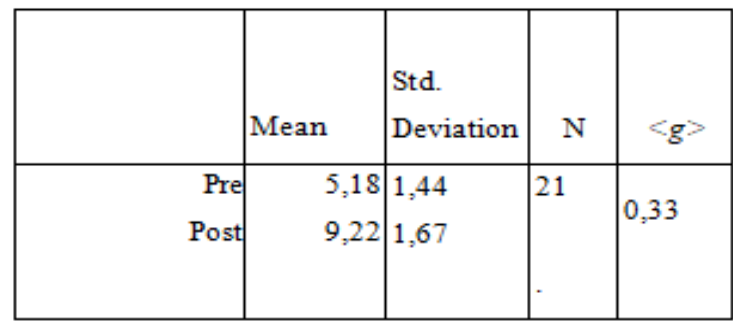

Gambar 2. Peningkatan Hasil Belajar Siswa

Berdasarkan tabel.2 diperoleh nilai rata-rata pretest sebesar 5,18 dan nilai rata-rata hasil belajar posttest sebesar 9,22 . Peningkatan hasil belajar setelah dilakukan uji gain ternormalisasi sebesar 0,33 dengan kategori sedang[19] dan dapat disimpulkan bahwa penggunaan multimedia interaktif dapat meningkatkan hasil belajar siswa pada pembelajaran IPA.

\section{B. Pembahasan}


Mata pelajaran IPA di Sekolah Dasar termasuk pada kelompok mata pelajaran Sains yang bertujuan memberikan pemahaman kepada siswa dapat memiliki keterampilan secara ilmiah meliputi aspek pengetahuan, skill, dan sikap. Dalam penelitian ini pengukuran dan penilaian dilakukan pada aspek sikap mencakup motivasi belajar siswa dan hasil belajar yang diukur pada ranah kognitif mencakup kemampuan siswa dalam memahami, mengaplikasikan, dan menganalisis.

Penerapan multimedia interaktif dapat meningkatkan motivasi belajar siswa kelas V SDN 2 Keresek dalam pembelajaran IPA. Berdasarkan uji gain peningkatan motivasi belajar diperoleh nilai 0,72 dengan kategori tinggi yang artinya peningkatan motivasi belajar setelah diberikan perlakuan penggunaan multimedia interaktif berada pada tingkat tinggi. Penggunaan multimedia interaktif telah menarik motivasi belajar siswa sebagai daya pendorong siswa dalam melakukan aktivitas belajarnya pada proses pembelajaran.

Multimedia yang memuat unsur-unsur teks, animasi, gambar, dan video telah menjadi daya tarik bagi siswa dalam memperoleh pengalaman belajarnya sesuai dengan gaya belajarnya secara mandiri. Senada dengan hasil penelitian [20][21] menyatakan bahwa penggunaan multimedia interaktif meningkatkan motivasi belajar siswa dan meningkatkan proses belajar mandiri. Selanjutnya hasil penelitian[22] menyatakan terdapat hubungan yang tinggi antara motivasi belajar siswa dengan prestasi belajar IPA siswa kelas V SDN 2 Keresek.

Hasil belajar siswa pada pembelajaran IPA menunjukan peningkatan sebesar 0,33 dengan kategori sedang berdasarkan dari hasil uji gain. Multimedia interaktif memiliki kelebihan diantaranya dapat memvisualisasikan materi yang bersifat abstrak menjadi konkret serta memiliki fungsi interaktif dan feedback bagi pengguna.

Sejalan dengan perlakuan yang diberikan pada penelitian ini, pengguna yang merupakan siswa telah memperoleh informasi/pesan/materi yang jelas sehingga pengetahuan siswa dalam memahami, mengaplikasikan, dan menganalisis materi yang disampaikan dapat mudah dipahami.

Kondisi tersebut berdampak pada perubahan yang signifikan pada hasil belajar siswa.Multimedia Interaktif sebagai media pembelajaran merupakan komponen dalam membentuk lingkungan belajar untuk meningkatkan kualitas belajar siswa[23][24].

\section{KESIMPULAN}

Penerapan multimedia interaktif dapat meningkatkan motivasi belajar dan hasil belajar pada pembelajaran IPA siswa kelas V SDN 2 Keresek Peningkatan motivasi belajar sebesar 0,72 dengan kategori tinggi dan peningkatan hasil belajar sebesar 0,33 kategori sedang.

Penggunaan multimedia interaktif perlu memperhatikan aspek kompleksitas dan observabilitas terkait dengan prosedur penggunaan yang dapat mudah digunakan oleh pengguna dan diamati guna mewujudkan tujuan pembelajaran yang diharapkan mengingat peran guru dalam pembelajaran tidak bisa digantikan dan digeserkan sepenuhnya dengan kehadiran media pembelajaran yang canggih, menarik, dan inovatif.

\section{UCAPAN TERIMA KASIH}

Terima kasih kepada seluruh pihak yang berperan memberikan kelancaran dan kemudahan dalam pengambilan informasi penelitian yang kami lakukan terutama kepada kepala sekolah SDN 2 Keresek Kecamatan Cibatu Kabupaten Garut.

\section{DAFTAR PUSTAKA}

[1] Munir, "Konsep dan Aplikasi dalam Pendidikan.pdf." Alfabeta., Bandung, 2015

[2] L. G. Husein, S. Herayant, "Pengaruh Penggunaan Multimedia Interaktif terhadap Penguasaan Konsep dan Keterampilan Berpikir Kritis Siswa Pada Materi Suhu dan Kalor. Jurnal," vol. 1, no. 3, p. 2015.

[3] W. Priyanto, "Penerapan Multimedia Interaktif Berbasis Inkuiri Terbimbing Dalam Pembelajaran IPS Siswa Kelas IV Sekolah Dasar. Jurnal Mimbar Sekolah Dasar. 2016. Vol. 3(2). p120-135,” vol. 3, no. 2, p. 2016.

[4] Y. Deliany, N. Hidayat, A. Nurhayati, "Penerapan Multimedia Interaktif untuk Meningkatkan Pemahaman Konsep IPA Peserta Didik di Sekolah Dasar. Jurnal Pendidikan dan Pembelajaran. 2019. Vol 17(2). p90-97," vol. 17, no. 2, p. 2019.

[5] D. Darmawan, "Teknologi Informasi dan Komunikasi.pdf." Rosdakarya, Bandung, 2013.

[6] B. Eka, "Konsep Dasar Multimedia.pdf." Graha Ilmu, Yogyakarta, 2013.

[7] A. H. Sutopo, "Teknologi Informasi dan Komunikasi dalam Pendidikan. Yogyakarta: Graha Ilmu,” p. 2012.

[8] Riyana, "Media Pembelajaran.pdf." CV. Wacana Prima, Bandung, 2007.

[9] A. H. Roblyer, M.D. \& Doering, "Integrating Educational Technology into Teaching . Boston: Pearson," 2010

[10] Sardiman, "Interaksi dan Motivasi Belajar Mengajar.pdf." Rajawali Pers, Jakarta, 2007.

[11] W. Sanjaya, "Kurikulum dan Pembelajaran. .pdf." Kencana, Prenada Media Group, Jakarta, 2009.

[12] W. Winkel, "Bimbingan dan Konseling di Institusi Pendidikan.pdf." Media Abadi, Yogyakarta, 2005.

[13] H. . Uno, "Teori Motivasi dan Pengukurannya : Analisis di Bidang Pendidikan. Jakarta: Bumi aksara," 2011.

[14] K. S. Sukoco, "Pengaruh Media Animasi Terhadap Hasil Belajar Dan Motivasi Belajar Siswa Materi Sistem Kelistrikan Otomotif Pendidikan Vokasi , 2013. Vol. 3 , 1 - 129,” vol. 3, p. 2013.

[15] Y. M. C. Chan and H. Yuan, "The Changes of Nursing Students' Assessment Skills at a Simulated Setting: A Quasi Experimental Study," Creat. Educ., vol. 05, no. 03, pp. 134-140, 2014, doi: 10.4236/ce.2014.53021.

[16] Sugiyono, "Metode Penelitian Pendidikan Pendekatan Kualitatif, Kuantitatif dan R\&D .," Bandung Alfa Beta., p. 2010, 2010.

[17] D. A. Abdushukurov, "Mathematical Modeling of the Efficiency Gadolinium Based Neutron Converters," vol. 2013, no. August, pp. $27-33,2013$

[18] S. Arikunto, Prosedur Penelitian Suatu Pendekatan Praktik, Rineka Cip. Jakarta, 2010.

[19] D. . Meltzer, "The Relationship between Mathematics Preparation and Conceptual Learning Grains in Physics: A Possible 'Hidden Variable' in Diagnostice Pretest Scores. American Journal Physics . 2002. Vol 70 (12), p1-27," vol. 70 , no. 12 , p. 2002

[20] E. Ghofur, A. Youhanita, "Interactive Media Development to Improve Student Motivation. International Journal of Education \& Curriculum Application. 2020. Vo 3(1). p1-6," vol. 3, no. 1, p. 2020.

[21] A. . Nugroho, "Interactive Multimedia and Mobile Application for 
Language Learning (Mall) Viewed From Motivation. Journal of English Language and Language Teaching . 2019. Vol 3(2). p1-10," vol. 3, no. 2, p. 2019.

[22] Y.. Lawe, "Motivation and Learning Achievement in Natural Science Subject of The Fifth Graders Of Elementary School: A Correlational Study. Jurnal of Educational Technology . 2017. Vol 1(1). p51-55," vol. 1 , no. 1 , p. 2017,2017

[23] M. Leow, F.T \& Neo, "Interactive Multimedia Learning: Innovating Classroom Education in A Malaysian University. The Turkish Online Journal of Educational Technology . 2014. Vol 3(2). p99-110," vol. 3, no. 2, p. 2014.

[24] H. Setiawan, "Implementation of Digital Learning Using Interactive Multimedia in Excretory System with Virtual Laboratory. Research and Evaluation in Education Journal . 2015. Vol 1(2).p212-224," vol. 1, no. 2, p. 2015. 